\title{
Professional mobility of the future officer: to the formulation of the development problem
}

\author{
T.P. Skripkina ${ }^{*}$, D.Yu. Naumov ${ }^{2}$, and I.S. Melentyev ${ }^{3}$ \\ ${ }^{1}$ Russian State University for the Humanities, Vygotsky Institute of Psychology, Moscow, Russia \\ ${ }^{2}$ Tambov State University named after G. R. Derzhavin, Tambov, Russia \\ ${ }^{3}$ Novosibirsk Military Institute named after General of the Army I.K. Yakovlev of the National Guard \\ of the Russian Federation, Novosibirsk, Russia
}

\begin{abstract}
In modern psychological and pedagogical studies, social and professional mobility is rarely correlated with the performance of military service duties. This circumstance is dictated by the ideas about the uniformity and legal «regulation» of military-service relations. The authors substantiate the need for the development of professional mobility, both on the vertical and on the horizontal layer, since the variety of duties performed by officers in the course of military work and the presence of various military positions to which he can be appointed, requires rapid adaptation to changing conditions of the social environment. The novelty of the research is that: the scientific results of the analysis of the structure of professional mobility of future officers are presented; the concept of «professional mobility of the future officer» is concretized based on the features of solving professional tasks by officers in the military; the conditions and means of developing the professional mobility of future officers are established and proposed.
\end{abstract}

\section{A problem statement}

Revealing the trends in the development of public relations and the complexity of the functioning of public structures, S.G. Chukin and P.Yu. Naumov noted the following: «The peculiarity of modern societies is their great differentiation, the reason for which is associated with changes in the content of social production: It has become high-tech, the service sector plays a significant role in it, and information is considered one of the most popular products today. As a result of these transformations, work at the machine, in the field, in transport, in other words, physical labor, which is traditionally associated with the creation of public wealth, has receded into the background, and in the ranking of professional occupations, the first places are occupied by people who are not directly related to material production: bankers, stock analysts and brokers, representatives of the IT industry, office «clerks». The emergence of many new professions and the fragmentation of the former ones radically changed the picture of public life...» [1].

\footnotetext{
* Corresponding author: prof-ped.gpa@mail.ru
} 
Within the framework of the paradigm of research of psychological and pedagogical problems that has developed in the social and humanitarian cognition, the professional mobility of the future specialist, as a characteristic of his abilities and readiness to perform a diverse set of professional functions, in the scope of various positions, both in the public and private sectors of the economy, occupies its place as relevant areas of study.

Trends in the actualization of knowledge and understanding of the essential characteristics of professional mobility, as a real factor in achieving high efficiency of professional work, also affect the scope of activities for preparing for armed defense and armed defense of the Russian Federation, i.e., the scope of performance of military service duties by professional military personnel.

To solve the problems of the «professional movement» of the future officer from one official level to another, from one line of service or military accounting specialty to another, it is necessary to conduct a comprehensive study of professional mobility, based on the ideas of a systematic approach, the concepts of integration of professional activities, the interpenetration of the values of military service in various areas of professional relations.

An important stage in the construction of theoretical arguments about the development of professional mobility of future officers as a complex systemic psychological phenomenon that functions in a changing social environment is to determine the conditions and develop appropriate tools that can be applied in the real pedagogical process to effectively support the development of professional mobility of future officers.

\subsection{The objective of the work}

The performance of the duties of military service, which includes professional service activities for the conscientious performance of all general, official and special duties, is so diverse that even at the legislative level, article 37 of the Federal Law «On Military Duty and Military Service» provides a very significant (but far from exhaustive!) a list of cases when a serviceman is considered to be performing the duties of military service. Consequently, professional activity as diverse in its content and form as military service, which includes both managerial, pedagogical, law enforcement, and physical-combat components, requires, perhaps more than any other, from the subject performing this activity, developed professional mobility, the ability to navigate in the professional space and the variety of duties and functions performed.

Thus, the purpose of this study is to specify the concept of «professional mobility of a future officer» based on the features of solving professional tasks by officers, analyzing the structure of professional mobility of future officers, determining the conditions and means of developing professional mobility of future officers.

\section{Results of the research}

The problem of formation and development of professional mobility, the search of pedagogical conditions and means of such development, and to identify its sociopsychological and essential characteristics studied in the scientific works of V.A. Klimova [2], O.G. Chekhov [3], L.V. Goryunova [4], B.M. Igoshev [5], L.P. Merkulova [6], O.Y. Posohova [7], V.A. Mishchenko [8], Gimpelson V.E. [9], S.E. Kaplino [10] etc.

The main scientific methods for conducting the study were: classical: analysis and synthesis, generalization, comparison, analogy, systematization, system analysis and modeling, etc.; empirical: survey, testing, performance analysis, conversation, observation; methods of mathematical, quantitative and qualitative processing of the obtained data. 
Professional mobility of specialists in various fields has been the subject of scientific research in a large number of scientific papers. Taking into account these works, and focusing on them, it is important to consider the approaches that are the starting points for us.

«In pedagogical and psychological research, the concept of "professional mobility» is defined as broadly applied to the personality of a specialist as a whole. Professional mobility of a teacher is considered by us in a narrow, «extraprofessional» sense and is defined as a dynamic integrative quality of a person, expressed in the awareness of the need for continuous professional self-education, in the readiness for successful professional adaptation and creative self-realization in the changing conditions of professional pedagogical activity» [12].

Among other things, « ... an important and problematic area of training of military personnel and employees is the adaptation of educational programs not only to the current level of development of science and technology, but also to build them for the real activities of the troops, through a larger-scale study in the pedagogical process of departmental regulatory legal acts, the development and implementation of real legal algorithms for solving the tasks assigned to the troops by law. This applies, first of all, to the development and study in the educational process of the legal algorithm for the protection of public order, in the performance of tasks to combat terrorism and extremism, the protection of important state facilities and special cargo» [13].

The key thesis about the cross-sections and layers of professional mobility is the idea of P.A. Sorokin that there are two main types of mobility: vertical and horizontal. The first one depends on a specific progressive movement on the career ladder and changes in the official position, the second one orients the subject of professional activity to change the position in the course of mastering the volumes of various positions, even if they are approximately at the same level [14].

E.F. Zeer suggests considering mobility through several interrelated concepts: subjectivity; interactivity; personal certainty; individual compatibility and socio-cultural and professional environment [15].

T.B. Kotmakova, understands mobility through the integration of personal and subjective qualities with the features of professional activity, through the knowledge and mastery of which professionalism and the ability to perform many labor and service functions are achieved. These personal characteristics are achieved on the basis of motivation and active creative self-development, and are fixed in the course of communication becoming personal attitudes [16].

A.K. Markova departed from the simplified models of vertical or horizontal professional mobility and identified several types of it at once, the criterion for distinguishing which is not the social movement, but the content of the activity (special mobility; social mobility; personal mobility; individual mobility) [17]. In our opinion, the concept of professional-subject mobility organically incorporates all its types, including those considered in the works of A.K. Markova.

L.A. Amirova did not establish the types of professional mobility, but rightly drew attention to the levels of its development, highlighting the basic or first level, the second or activity level, the third or competence level, and giving their convincing sociopsychological characteristics [18].

Studies of professional mobility of officers are found in the psychological and pedagogical discourse. So it is noted that «The problem of the psychological essence, structure and content of professional mobility of a specialist today is in the attention of various theorists and practitioners. Increasing the relevance of professional mobility research is associated with the further transition of our economy to improving the quality of 
services provided and the competitiveness of not only goods (services) but also specialists themselves» [19].

Earlier, we noted that: «It would be a mistake to assume that professional mobility is a quality and characteristic of a person that is not relevant for military specialists with higher education. Passing training and graduating from the military educational organization of higher education of the National Guard troops of the Russian Federation, an officer must be prepared not only to solve a certain amount of functional (general, official, special) duties, but also to move up the career ladder and perform tasks not only of the primary officer level - platoon commander (rifle platoon, shift supervisor) but also the deputy commander of the company for work with personnel, the commander of the company (military commandant's office), the assistant chief of staff, the head of the group for work with personnel, the senior assistant to the head of the legal support group (interrogator), the assistant commander of the military unit for legal work - the head of the legal support group and others» [20].

\section{Conclusions}

Based on the analysis of the scientific literature, the professional mobility of the future officer is understood by us as their personal characteristic, which combines the ability and willingness to quickly adapt to the service, change the content of official and functional duties, move up the career ladder, including when moving from one organization (institution, military unit, territorial body) to another and change the direction of official activity (command, legal, moral and psychological, etc.). The multidimensional nature of professional mobility of future officers is revealed through its social-adaptive, activityservice, communicative-organizational, managerial-subjective, reflexive-value and cognitive characteristics.

The study of the educational environment and the needs of the troops in socially and professionally mobile officers, allows us to assert that the conditions for the development of professional mobility of future officers are: familiarization of the future officer with the content of official duties in various military positions (for various military accounting specialties); familiarization of the future officer with the content of special duties performed during participation in the maintenance of special legal regimes and military outfits; comprehensive early professionalization and professional orientation of cadets with the participation of representatives of operational-territorial associations, formations, territorial bodies and military units of the National Guard of the Russian Federation; modeling during the educational process of solving real professional tasks in various military positions (in various military accounting specialties); formation of the value attitude and motivation of cadets to master the optimal personal level of professional mobility, competitiveness and creative solution of professional tasks.

The means of developing the professional mobility of future officers include: a) a program of adaptation of cadets to the conditions of military service in the performance of duties in military positions to be replaced by officers; b) a program of psychological support for the training and daily activities of cadets; c) conducting psychological counseling to explain the functions of professional mobility in the activities of an officer; d) a standard training course «Duties in military positions, based on the military accounting specialty»; e) development of a program of psychological assistance to officers when they are appointed to new military positions.

The development of professional mobility of officers is influenced by the social situation in the state and society, the level of material security of personnel, the flexible content of educational programs and qualification requirements, the needs of state customers (represented by military units and bodies), but the main thing remains that 
professional mobility cannot be developed if the future officer is not prepared for the reality and specifics of military activity, in all its variety of manifestations.

\section{References}

1. S.G. Chukin, Justice today: a difficult choice between distribution and recognition, Ideas and Ideals, 3(29), 81-92 (2016)

2. V.A. Klimov, Professional psychology: ed. psikhol. tr., 286 (2003)

3. O.G. Chekhov, Formation of professional mobility of teachers of preschool educational institutions in the process of professional development, 166 (2013)

4. L.V. Goryunova, Professional mobility of a specialist as a problem of developing education in Russia, 39 (2006)

5. B.M. Igoshev, Professional mobility of teachers: organizational and pedagogical aspect, News of the Ural State University, 56, 34-40 (2008)

6. L.P. Merkulova, Formation of professional mobility of technical specialists by means of a foreign language, 40 (2008)

7. O.Yu. Posukhova, Trends of professional mobility in modern Russian society, Postgraduates and Young Scientists, I, 203-205 (2006)

8. V.A. Mishchenko, Professional mobility as one of the main psychological and pedagogical qualities of a future specialist, Journal of the Samara Scientific Center of the Russian Academy of Sciences, 2-5, 13 (2011)

9. V.E. Gimpelson, R.I. Kapelyushnikov, Choice of profession: what did you learn and where did you come in handy?, Professional education. Capital, 8, 19-21 (2009)

10. S.E. Kaplina, Conceptual and technological foundations for the formation of professional mobility of future engineers in the process of studying humanitarian disciplines, 46 (2008)

11. Yu.Yu. Dvoretskaya, Psychology of professionally mobile personality, 147 (2007)

12. V.V. Kosukhin et al., Actual problems of professional training of military personnel and employees of the Russian Guard, In the collection: Directions and prospects for the development of education in military institutes of the National Guard troops of the Russian Federation. Collection of scientific articles of the XII Interuniversity Scientific and Practical Conference with international participation. Under the general editorship of V.V. Kosukhin, 131-136 (2020)

13. P.A. Sorokin, Chelovek. Civilization. Society, 543 (1992)

14. E.F. Zeer, Modernization of professional education: a competence-based approach, Education and Science, 3, 42-53 (2004)

15. T.B. Kotmakova, Formation of personal mobility as a professional quality of future specialists in the process of training at a university, 198 (2011)

16. A.K. Markova, Psychology of professionalism, 308 (1996)

17. L.A. Amirova, Development of the qualities of a mobile personality at the stage of pre-professional socialization, 194 (2011)

18. P.Yu. Naumov et al., Means of development of professional mobility of the future officer, In the collection: Problems of effective use of the scientific potential of society. Collection of articles on the results of the International Scientific and Practical Conference, 115-117 (2020) 
19. P.Yu. Naumov et al., Psychological and pedagogical conditions for the development of professional mobility of the future officer, In the collection: Problems of effective use of the scientific potential of society. Collection of articles on the results of the International Scientific and Practical Conference, 117-120 (2020) 